\title{
Historein
}

Vol $11(2011)$

Politics and History

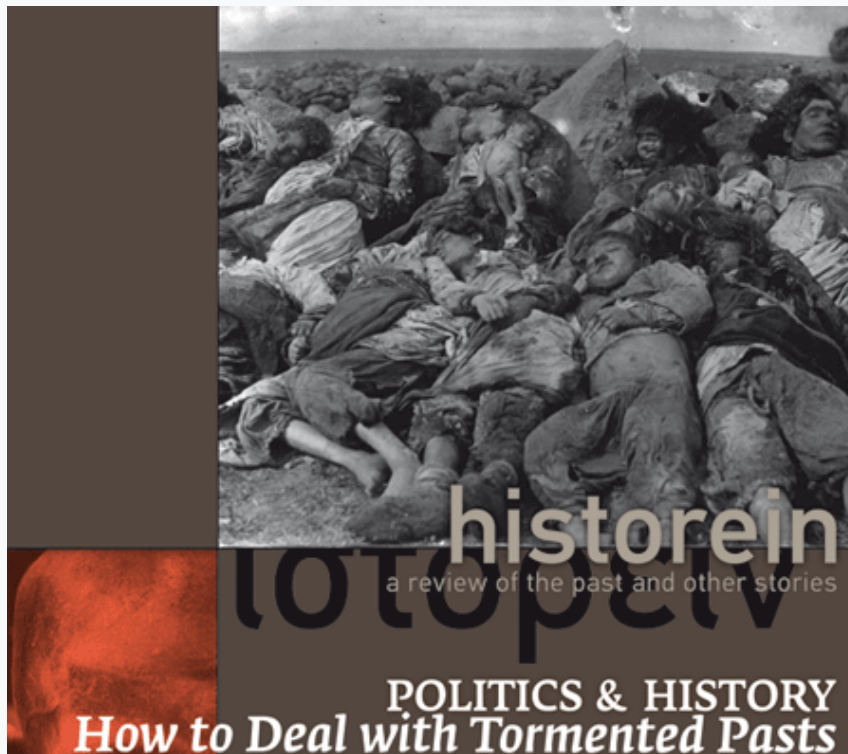

\section{Criminal Laws on History: The Case of the European Union}

Luigi Cajani

doi: $10.12681 /$ historein.138

\section{Copyright ( 2 2012, Luigi Cajani}

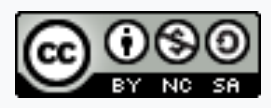

This work is licensed under a Creative Commons Attribution-NonCommercialShareAlike 4.0.

\section{Pierre Nora \\ Jörn Rüsen \\ Wolfgang Benz \\ Luigi Cajani \\ Antoon De Baets}

To cite this article:

Cajani, L. (2012). Criminal Laws on History: The Case of the European Union. Historein, 11, 19-48.

https://doi.org/10.12681/historein.138 
Since the early 1990s, one can observe in Europe a proliferation of memory wars and controversies related to tragic historical events. The reasons are many and both of a domestic and international nature: the multicultural transformation of many societies that has involved the self-assessment of previously silent communities, which demand public recognition for what they consider their own historical identity; the crisis of Cold War political ideologies, which has given representation to political actors which were previously marginalised from the main historical narrative of states; ${ }^{1}$ tensions with former colonies, which claim reparations for colonial crimes and the slave trade; ${ }^{2}$ and the collapse of the Soviet Union, with the birth of new states which want to come to terms with past wounds.

A particular feature of these memory wars is the use of the penal code in order to enforce a unique, official interpretation of these events and to punish diverging opinions. A corpus of new laws is thus being established, which are often mutually influenced and which have given rise to concerns over their impact on the freedom of expression and particularly on the freedom of historical research. Historians are in fact directly targeted by the provisions of these laws, alongside journalists, teachers, politicians and anybody who makes use of historical discourse.

A significant example of these conflicts and of the political bias on historical discourse is the Holodomor, the famine of 1932-33 in Ukraine, which is matter of heated controversy not only between Russia and Ukraine

\section{Criminal Laws on}

\section{History: The Case of}

\section{the European Union}

\section{Luigi Cajani}

Sapienza University of Rome 
but also inside Ukraine. Historians debate on the interpretation of this event: some maintain that it was a genocide planned by the Soviet regime in order to crush Ukrainian resistance against collectivisation while others consider it rather as the consequence of gross mistakes on the part of the regime, which, unable to face an agricultural crisis, actually worsened it but which did not have the intention of targeting the Ukrainian people. ${ }^{3}$

On 28 November 2006 Ukraine's parliament passed a law ${ }^{4}$ declaring the Holodomor an act of genocide against the Ukrainian people, and added that its public denial should be considered as dishonouring the memory of the millions of victims and humiliating the dignity of the Ukrainian people, and, therefore, be deemed unlawful. The issue was very much debated between the opposing anti-Russian and pro-Russian fronts, the former represented by President Viktor Yushchenko, who accepted the famine's characterisation as genocide, and the latter by his opponent Prime Minister Viktor Yanukovich, who rejected it, arguing that the famine was the outcome of the mass collectivisation of farms which affected the whole Soviet Union and not specifically Ukraine. The divided opinion was mirrored by the vote: only $233 \mathrm{MPs}$ supported the bill - a minimum of 226 votes was required for it to be passed - while 200 deputies abstained.

This law had, of course, an international resonance. The Ukrainian government in fact acted in order to have other states recognise the quality of genocide. On 28 May 2008, Canada, where there is a strong community of Ukrainian origin, recognised the "Ukrainian Famine of 1932-33 as an act of genocide" and established an Ukrainian Famine and Genocide ("Holodomor") Memorial Day, ${ }^{5}$ but without foreseeing a punishment for its denial. Also, the European Parliament recognised, on 23 October 2008, the Holodomor as "an appalling crime against the Ukrainian people, and against humanity". The text of the resolution avoided using the term "genocide", but in any case backed an interpretation which charged the Soviet government with the intention of targeting Ukraine: "[It] was cynically and cruelly planned by Stalin's regime in order to force through the Soviet Union's policy of collectivisation against the will of the rural population in Ukraine."6 On the opposite side, the Russian Duma on 2 April 2008 approved a statement which expressed sorrow for the famine tragedy which struck much of the Soviet Union in the 1930s, but rejected the charge of genocide, asserting that "there is no historical evidence that the famine was organised along ethnic lines. Its victims were millions of Soviet citizens, representatives of different peoples and nationalities living largely in agricultural areas of the country."7

The Parliamentary Assembly of the Council of Europe discussed the Holodomor in early 2010, and was directly affected by the domestic Ukrainian controversy. It received in fact three documents: two, from the Our Ukraine party and the Yulia Tymoshenko Bloc, respectively, which supported the interpretation of the famine as genocide, and another from the Party of Regions, which supported Yanukovych, who in February 2010 succeeded Yushchenko as state president, which asserted that the famine did not fully meet the criteria established for the crime of genocide by the UN Convention on the Prevention and Punishment of the Crime of Genocide of 1948. ${ }^{8}$ On 27 April 2010 Yanukovych attended a sitting of the Parliamentary Assembly, and when asked about his opinion on this pending issue, declared that the great famine of the 1930s had affected the Volga region, Belarus and Kazakhstan as well as Ukraine. He added that it had been a consequence of the policies of the Stalinist regime, and all countries had been affected. To recognise 
the Holodomor as genocide in respect of one or another people, he said, would be incorrect and unfair. It had been a shared tragedy between all members of the Soviet Union. ${ }^{9}$

Encouraged in this way, on the following day the Parliamentary Assembly passed a resolution that stated "Millions of innocent people in Belarus, Kazakhstan, Moldova, Russia and Ukraine, which were parts of the Soviet Union, lost their lives as a result of mass starvation caused by the cruel and deliberate actions and policies of the Soviet regime."10

On the issue of genocide, the resolution avoided a clear position: it simply mentioned that Ukrainian law recognised the famine as a genocide, without further comment. This cautious attitude had been actually suggested by the rapporteur, Mevlüt Çavuşoğlu, who observed that it was not opportune to back the thesis of genocide because in Ukraine historians and politicians were not unanimous on that and also because "I firmly believe that politicians, both on the national and on the international level, should avoid being involved in the interpretation of historical facts of the past."11 In the context of the current history wars, this was a very significant stance for a politician to take.

Yanukovych's words in Strasbourg show how a political change can bring about change in an official historical interpretation. But Ukrainian law was still there, and on the basis of it Volodymyr Volosiuk, a member of the People's Movement of Ukraine, a political party which opposed Yanukovych, sued him for this statement and asked the court to oblige the president to apologise before him and the Ukrainian people. ${ }^{12}$ Eventually, after a judicial path through some courts, on 8 December 2010 the Kyiv Court of Appeals acquitted Yanukovych. ${ }^{13}$ One might think that it would have been difficult for the court to condemn the president, but in any case it seems that, despite the law, the behaviour of the Ukrainian courts is not uniform. In fact, in January 2010 an Ukrainian court declared Joseph Stalin and several other senior Soviet officials guilty of genocide. ${ }^{14}$ But the following March, a court in the Donetsk region, in eastern Ukraine, refused to prosecute the editor of the Rodnoye Priazovye newspaper, who in an article had written that the Holodomor was not a genocide..$^{15}$ This represents a worrying absence of legal certainty, which reflects the split in Ukrainian public opinion.

\section{The prosecution of Holocaust denial}

The wave of criminal laws on history has its origin and model in the laws against the denial of the Holocaust. The first one was approved in Israel in 1986, and punished with five years' imprisonment "any statement denying or diminishing the proportions of acts committed in the period of the Nazi regime, which are crimes against the Jewish people or crimes against humanity, with intent to defend the perpetrators of those acts or to express sympathy or identification with them". ${ }^{16}$ In this text one must underline two points in order to allow for a comparison with similar laws. First, the definition of the criminal conduct: not only the simple and total denial of the event, but also the diminution of its size; and second, the restrictions placed on the prosecution: the aforementioned criminal conduct must be qualified by a clear, positive attitude towards the perpetrators. 
Meanwhile, in Europe too the introduction of such a law was discussed as a response to the increase in incidents of anti-Semitism, often in connection with extreme right parties, and in cases of Holocaust denials. First came France in 1990 with the so-called Gayssot law (loi Gayssot). ${ }^{17}$ This law, which had the general intent of suppressing "every act of racism, anti-Semitism or xenophobia", imposed one year's imprisonment and a heavy fine (equivalent to $€ 45,000$ today) on those who disputed "the existence of one or more crimes against humanity defined by article 6 of the Charter of the International Military Tribunal appended to the London Agreement of 8 August 1945", which made up the legal basis of the Nuremberg trials. ${ }^{18}$ For the identification of these crimes against humanity, both the competence of international and French courts was recognised. Concerning the nature of the criminal conduct targeted by the Gayssot law, one must note that the French text uses the verb "contester", which means not only "to deny" but also "to dispute" and "to doubt". This semantic pluralism produces, therefore, a certain ambiguity in the interpretation of the conduct. With the French law, in any case, the simple criminal conduct is prosecuted, with no need of qualification, as in the Israeli law. The French Human Rights League (Ligue des Droits de l'Homme) criticised the Gayssot law for being useless in the fight against racism and dangerous for freedom of the press and of research: ${ }^{19}$ an argument which often recurs in the debates about prosecuting Holocaust denial. In an article written in 1990, the historian Madeleine Rebérioux added that this law was even superfluous, as shown by the fact that Robert Faurisson, a well-known Holocaust denier, had been convicted ${ }^{20}$ for his statements in 1981, when this law did not exist, on the base of the provisions that punished defamation. Moreover, she continued, judges and historians have different tasks and different strategies, which must not be confused: "Historical truth refuses the authority of a state," she concluded. In a 1996 article, she also foresaw that this law would open the way to the definition of an official historical truth also for other genocides. ${ }^{21}$

Rebérioux' clairvoyance was confirmed by the subsequent set of memory laws (lois mémorielles) that were approved in France under the pressure of various social groups.

French citizens of Armenian descent endorsed the law of 29 January 2001 by which France recognised the "Armenian genocide" in the Ottoman Empire during the First World War. ${ }^{22}$ By its wording, this law thus assessed the existence of an historical event and its interpretation at the same time. While the law did not foresee a punishment for denial, this was soon to come, following the pattern of Holocaust denial. In fact, in April 2006 the Socialist MP Didier Migaud presented a bill on the Armenian genocide that extended the 2001 law by introducing the same penalty established in the Gayssot law. This bill was approved by the National Assembly on its first reading, on 12 October $2006,{ }^{23}$ but in order to come into force it needed the approval of the Senate, which deferred making a decision for years before eventually rejecting it on 4 May 2011. During the debate in the Senate, one of the main arguments introduced by the rapporteur, JeanJacques Hyest, was that it was not the task of legislators to give juridical definitions of the past and to connect these definitions with criminal penalties. ${ }^{24}$

French citizens of black African descent promoted the Taubira law (loi Taubira), approved on 21 May 2001, which defined as crimes against humanity both the slave trade, in the Atlantic and Indian oceans, and slavery itself, practiced from the fifteenth century onwards "in America, in the 
Caribbean region, in the Indian Ocean and in Europe against the African, Amerindian, Madagascan and Indian peoples". ${ }^{25}$ This law also prescribed that the slave trade and slavery must be allowed "the position they deserve" both in school programmes and in historical research. ${ }^{26}$ This law, too, did not introduce any penalties.

Initially, these two laws did not arouse any serious concern among historians and history teachers, but in 2005 a scandal erupted with the passing, on February 23, of the Mekachera law (loi Mekachera) on French colonialism, promoted by the lobby of the pieds noirs (French citizens repatriated after the end of the Algerian war). The law declared that "The nation expresses its gratitude to women and men who participated in the activities carried out by France in the former French départements in Algeria, Morocco, Tunisia and Indochina and in the other territories previously under French sovereignty."27

Like the Taubira law, the Mekachera law dictated that the history of the French people overseas, and especially in north Africa, should be allowed the "position it deserves" in academic research; but then it went much further, prescribing that school programmes should also recognise the "positive role" played by the French people in that context. ${ }^{28}$ This latter clause, which enforced the precise interpretation of an historical event and therefore directly interfered with historical research and history teaching, immediately raised a storm of protest in France. ${ }^{29}$ The protest soon turned even more fiery because of an incident that showed how this new set of laws could become a dangerous tool to attack or blackmail historians. In September 2005, the Collective of Antilleans, Guyanese and Réunionnais (Collectifdom) sued the French historian Olivier PétréGrenouilleau, author of an important study on the African slave trade, ${ }^{30}$ on the charge of "denial of crimes against humanity". This charge was based on a newspaper interview ${ }^{31}$ in which PétréGrenouilleau had maintained that the slave trade could not be regarded as a case of genocide and where he criticised the Taubira law in particular because, by defining the slave trade as a crime against humanity, it suggested an inappropriate comparison with the Holocaust. Patrick Karam, the president of Collectifdom, also announced that he would appeal to the competent authorities with a request that Pétré-Grenouilleau be suspended from academic teaching.

The reaction of the academic world was very strong, and led to an appeal entitled Liberte pour l'histoire, ${ }^{32}$ which requested the abolition of all the memory laws, on the grounds that "in a free state, neither parliament nor the judicial authorities are entitled to define historical truth". The mobilisation was eventually successful: indeed, the second clause of art. 4 of the Mekachera law, concerning the teaching of history, was abolished in January 2006, after the Constitutional Council had declared that French laws could not contain a prescription of that kind, ${ }^{33}$ and in the following February Collectifdom, confronted with these protests, withdrew its legal action against Pétré-Grénouilleau. ${ }^{34}$

Meanwhile, after France other European states had adopted laws against Holocaust denial, with some relevant differences. In 1992 Austria introduced a new article to the Verbotsgesetz (prohibition act), the 1947 law against Nazi activities, punishing with one to ten years' imprisonment (or twenty years' in case of a particularly serious offense) those who "deny, grossly minimise, approve or try to justify" genocide and other Nazi crimes..$^{35}$ Thus other criminal conducts, typical 
forms of crimes of opinion, were added to the denial category and became very successful, and were adopted by many jurisdictions.

Germany in 1994 added to section 130 of the Strafgesetzbuch (criminal code), under the heading of "Incitement to hatred" (Volksverhetzung), a paragraph which punished with a fine or prison sentence of up to five years "whosoever publicly or in a meeting approves, denies or downplays an act committed under the rule of National Socialism ... in a manner capable of disturbing the public peace". ${ }^{36}$ This law came after ten years of parliamentary debates, during which the possibility of including other crimes against humanity was also discussed, but this idea was dropped because, it was felt, this would have belittled the special responsibility of Germany towards Nazi crimes. $^{37}$

A Belgian 1995 law punished the "denial, minimisation, justification or approval" of the Nazi genocide with a fine or imprisonment from eight days to one year. ${ }^{38}$ In 2005 the extension of this law to cover other genocides was also discussed. The Belgian lower house approved a draft bill which included genocide and other crimes against humanity defined as such by every international court recognised by Belgium, by the Security Council or the General Assembly of the United Nations, and by a national court in Belgium or any other European Union member state. ${ }^{39}$ But in the event the Senate did not approve the project, which has not surfaced since. ${ }^{40}$

Luxembourg in 1997 introduced a new penal prosecution of racist acts, including art. 457.3 of the penal code, which punished those who "disputed, minimised, justified or denied the existence of one or more crimes against humanity and war crimes defined by article 6 of the Charter of the International Military Tribunal appended to the London Agreement of 8 August 1945".41 For these crimes it recognised the jurisdiction of Luxembourgian, foreign and international courts. The sentence was eight days to six months' imprisonment and a fine ranging from 10,001 to $1,000,000$ francs, or only one of them. These provisions were also extended to cover genocides committed by states other than Nazi Germany, and in these cases only Luxembourgian and international courts were recognised.

In 2002 Romania decided to punish "organisations and symbols with fascist, racist and xenophobic character" and the cult of personalities responsible for crimes against peace and humanity and for war crimes who were found guilty by a national or international court. ${ }^{42}$ In addition, the denial of the Holocaust was explicitly mentioned and punished by imprisonment from six months to five years and the suspension of rights. ${ }^{43}$

Other states have approved laws which punish denial and related criminal conducts in relation to genocide and crimes against humanity in general, without an explicit reference to those perpetrated by the Nazis. Art. 261 bis of Switzerland's penal code, introduced in 1993,44 punishes by a fine or by imprisonment of up to three years those who "deny, grossly minimise or try to justify a genocide or other crimes against humanity". Under art. 240 of the penal code, in 2007 Portugal introduced the punishment for the denial of war crimes, crimes against peace and crimes against humanity, the penality being imprisonment from six months to five years. ${ }^{45}$ With no reference to the Holocaust or even an explicit mention of genocide, this article rather refers to the 
three crimes envisaged by the Charter of the International Military Tribunal. Noteworthy is also the fact that only the denial of these crimes is prosecuted, and only in connection with public defamation or insult against individuals or groups because of race, colour, ethnic or national origin, religion, sex or sexual orientation.

Spain is a case of particular interest. In 1995 a new article (607.2) was added to the penal code, which punished both the denial and the justification of genocide, without specifying the Holocaust or any other, and without mentioning crimes against humanity. ${ }^{46}$ But on 7 November 2007 the Spanish constitutional court (Tribunal Constitucional) declared it partially unconstitutional, affirming that only the justification of genocide can be prosecuted because it may amount, unlike the simple denial of it, to an incitement to violence. ${ }^{47}$ Thus the simple denial of genocide is considered a legitimate form of the freedom of speech, and it was erased from art. 607.2.

A peculiar agenda has been adopted by some countries of eastern Europe in connection with the coming to terms of their postwar relations with the Soviet Union and of their own communist regimes. Poland in 1998 created the Institute of National Remembrance (Instytut Pamięci Narodowej) in order to investigate crimes committed in the country by the Nazi, Soviet and Polish communist regimes, and also other crimes against peace, crimes against humanity and war crimes, ${ }^{48}$ and imposed a fine or prison sentence of up to three years for the public denial of these crimes. ${ }^{49}$ In 2002, the Czech Republic introduced art. 261a of the penal code ${ }^{50}$ which lumps Nazi and the communist crimes together: "Whoever publicly denies, questions, approves or tries to justify Nazi or communist genocide or other crimes against humanity committed by Nazis or communists shall be punished by a term of imprisonment from six months to three years."

All these laws make up a complex and heterogeneous picture which has its focus in the punishment of the denial of the Holocaust as a form of anti-Semitism, and therefore of racism, and which has been enlarged to encompass other historical events. The fact that the denial of the Holocaust is prosecuted does not affect historical research, because denial is totally unscientific. One can discuss whether the prosecution of Holocaust denial is effective and correct only on a social and legal level $\left.\right|^{51}$ - and indeed this is a constant subject of debates. The very problem arises when legislators move from the prosecution of the denial of an historical event to the prosecution of the denial of their own official interpretation of an historical event, which, on the contrary, interferes with the freedom of historical research. By that, a fundamental conceptual shift, or rather a leap, is achieved, which is the real core of the problem. There is, in fact, no equivalence or continuity between the denial of the existence of an event, such as the Holocaust, and the denial of an opinion on an event whose existence is not denied. Moreover, one must also consider that the definition of genocide is far from having met general agreement among jurists and historians. Henry Huttenbach, editor of the Journal of Genocide Research, clearly depicted the state of the question in 2002:

To date, genocide ... lacks both a satisfactory conceptual definition and a consensus as to the inner make-up of genocide. Without a conceptual definition one is impeded in separating genocidal events from the non-genocidal; and, lacking a basic blueprint, it is unclear how and what to compare and, thereby, determine distinctive singularities and commonalities separating and linking genocides. ${ }^{52}$ 
Scholars' opinions differ about the definition of genocide in terms of the intent and methods of the perpetrators and of the characteristics of the victims, ${ }^{53}$ and, therefore, also about the actual cases of genocide. Some scholars limit the definition of genocide only to the Holocaust (the thesis of the "uniqueness of the Holocaust"); others extend it to a great number of historical events, including the "colonial genocides" of the Herero, the Australian Aborigines and the Native Americans, with some finding cases as far back in history as antiquity. ${ }^{54}$ Also the definition of a war crime is a matter of debate: Anthony Grayling, a British philosopher, asserts that the air raids carried out by the Allied forces against German and Japanese cities during the Second World War were crimes against humanity. ${ }^{55} \mathrm{All}$ in all, there is not - and there cannot be - a solid base for fixing in law a definition of historical events of this kind.

Within this legiferation on history one can identify different trends as regards the definition of the criminal conducts and the historical events that are their object. Concerning the criminal conducts, in some states only the denial is prosecuted; on the contrary other states have added other conducts: approval, dispute, justification and (gross) minimisation. While denial and approval can be clearly enough defined, the meanings of dispute, justification and minimisation are rather blurred, and can lead to great uncertainties in judgment, and, therefore, to abuse. According to some jurists, for instance, justification and minimisation can mean that an historical event defined as a crime is explained or its gravity is diminished according to the context where it happened, for instance if it is considered as the reaction to a danger or to a previous act of violence. ${ }^{56}$ Moreover, some states punish these crimes in their simple form, while others punish them only when they are qualified. Concerning the historical events themselves, some states only mention the Holocaust, others refer to the crimes prosecuted by the Nuremberg tribunal, others include the crimes of communist regimes, while others generally speak about genocide or crimes against humanity perpetrated by whomsoever, thus opening up the way to the inclusion of every possible historical event characterised by mass massacres. And there is an additional problem: which authorities are recognised as being entitled to define an historical event as a crime? Some states clearly specify national or international tribunals, but others do not, thus creating an area of uncertainty about what conduct is punished and where. To take the case of the Belgian draft bill discussed in 2005, which recognises the sentences of many international courts and of the national courts of all European Union member states: what would happen in the case where the courts of two or more states delivered conflicting sentences?

One has finally to remark that many states are absent from this picture: for instance the United Kingdom, Ireland, Sweden, Denmark and the Netherlands have laws against racism, incitement to racial hatred and discrimination, but do not explicitly punish the denial of the Holocaust and also do not have criminal laws on other historical events. The reason is that these states have a strong tradition of safeguarding the freedom of speech. That shows that in the European Union there are two different areas of juridical tradition: a contradiction that the European institutions have tried to overcome. 


\section{The initiatives of the European institutions}

European institutions have constantly affirmed the will to create a European identity consisting, among other shared values, of the fight against racism and discrimination. ${ }^{57}$ With this aim they have promoted an unrelenting set of initiatives in order to approximate the penal provisions of the member states.

The first step in this direction was the Joint Action ... to Combat Racism and Xenophobia of $1996,{ }^{58}$ which established the judicial cooperation of the member states in order to fight the following criminal conducts:

(a) public incitement to discrimination, violence or racial hatred in respect of a group of persons or a member of such a group defined by reference to colour, race, religion or national or ethnic origin;

(b) public condoning, for a racist or xenophobic purpose, of crimes against humanity and human rights violations;

(c) public denial of the crimes defined in Article 6 of the Charter of the International Military Tribunal appended to the London Agreement of 8 April 1945 insofar as it includes behaviour which is contemptuous of, or degrading to, a group of persons defined by reference to colour, race, religion or national or ethnic origin;

(d) public dissemination or distribution of tracts, pictures or other material containing expressions of racism and xenophobia;

(e) participation in the activities of groups, organisations or associations, which involve discrimination, violence, or racial, ethnic or religious hatred..$^{59}$

This text defined two criminal conducts: condoning and denial. The former was related to every crime against humanity $(\S b)$, and the latter was related to the Nazi crimes prosecuted by the Nuremberg tribunal $(\S c)$, thus creating a difference, which seems to imply that only the Holocaust can be an object of denial, while other crimes are not denied but only condoned - what is in fact the case. The prosecution was based on the specific circumstances: racist or xenophobic purposes $(\S b)$, and contemptuous or degrading behaviour towards a group of persons defined by racial, religious or ethnic features $(\S c)$. These restrictions were relevant insofar as the simple condoning and denial were not criminalised, unlike in some laws which were already in force.

This Joint Action had a seminal but scarcely effective role, and its purposes were picked up again by a new of juridical tool, the Framework Decision on Combating Racism and Xenophobia, ${ }^{60}$ submitted by the European Commission on 29 November 2001. Article 4 of this first proposal followed the footprints of the Joint Action of 1996, but with some important differences: the contemptuous or degrading circumstances were dropped for the punishment of the denial or trivialisation of the crimes prosecuted by the Nuremberg tribunal, and in their place was introduced the likelihood of disturbing public order:

Member states shall ensure that the following intentional conduct committed by any means is punishable as criminal offence: 
(a) public incitement to violence or hatred for a racist or xenophobic purpose or to any other racist or xenophobic behaviour which may cause substantial damage to individuals or groups concerned;

(b) public insults or threats towards individuals or groups for a racist or xenophobic purpose;

(c) public condoning for a racist or xenophobic purpose of crimes of genocide, crimes against humanity and war crimes as defined in Articles 6,7 and 8 of the Statute of the International Criminal Court;

(d) public denial or trivialisation of the crimes defined in Article 6 of the Charter of the International Military Tribunal appended to the London Agreement of 8 April 1945 in a manner liable to disturb the public peace;

(e) public dissemination or distribution of tracts, pictures or other material containing expressions of racism and xenophobia;

(f) directing, supporting of or participating in the activities of a racist or xenophobic group, with the intention of contributing to the organisation's criminal activities.

Like in the Joint Action, the criminal conducts are unevenly attributed: condoning was referred to the crimes defined by the Statute of the International Criminal Court, while for the crimes prosecuted by the Nuremberg tribunal, the prosecuted conducts were denial and - what was new in comparison to the Joint Action - trivialisation. Art. 6 sets the general features of the penalties, which had to be "effective, proportionate and dissuasive" ( $\$ 1)$, and in particular it states that "the offences referred to in Article 4(a) and (f) are punishable by terms of deprivation of liberty with a maximum penalty that is not less than 2 years" (§ 3), thus giving the impression that these criminal conducts deserved more attention than those described in the other subparagraphs.

At the same time, the Council of Europe was also active in the fight against racism, xenophobia and negationism, by opening to signature on 28 January 2003 the Additional Protocol to the Convention on Cybercrime, Concerning the Criminalisation of Acts of a Racist and Xenophobic Nature Committed through Computer Systems, which in art. $6 \S 1$ invited member states to punish the distribution through computer systems of

material which denies, grossly minimises, approves or justifies acts constituting genocide or crimes against humanity, as defined by international law and recognised as such by final and binding decisions of the International Military Tribunal, established by the London Agreement of 8 August 1945, or of any other international court established by relevant international instruments and whose jurisdiction is recognised by that Party.

In comparison with the Framework decision, there is a unique set of criminal conducts: some of them are similar (with slightly different words) to those of the Framework decision, but there is the addition of justification. Concerning the tribunals entitled to assess the crimes that cannot be denied or trivialised and so on, the Nuremberg tribunal is the only one which is explicitly mentioned here, while the International Criminal Court is replaced by a reference to other international courts, implicitly meaning the addition also of those on the former Yugoslavia and on Rwanda created by the UN Security Council in 1993 and 1994, respectively, and any future courts of this kind. 
Unlike in the Framework decision, the Additional protocol also allows the prosecution of the simple criminal conducts (art. $6 \S 1$ ). This provision has nevertheless a restriction, because the following paragraph ( $\$ 2 a$ ) gives to each state the possibility of prosecuting the conducts described above only if they are qualified, meaning in case that they were committed "with the intent to incite hatred, discrimination or violence against any individual or group of individuals, based on race, colour, descent or national or ethnic origin, as well as religion if used as a pretext for any of these factors, or otherwise".

But most relevant - and surprising - is the provision of the final paragraph (art. $6 \S 2 \mathrm{~b}$ ) which reserves to each state the right "not to apply, in whole or in part, paragraph 1 of this article". Thus, states have total freedom in the adoption of the Additional protocol: they can punish only one criminal conduct, or they can limit the application only in relation to genocide and not to crimes against humanity, and they can even punish nothing at all and ignore this article. On this point the Additional protocol is totally different from the Framework decision, which instead is compulsory. This clause allows us to understand the disagreement inside the membership of the Council of Europe on the penalisation of denial and of the other related criminal conducts. And in fact, among the states which up to 31 July 2011 have signed the Additional Protocol, Denmark, Finland, Norway, Ukraine have made use of the rights in art. $6 \S 2 \mathrm{~b}$, and quite a few states have not signed the Additional protocol at all, including Italy, Russia, Sweden and the United Kingdom. ${ }^{61}$

The Framework decision declared by art. $16 \S 1$ that the member states had to take the necessary measures to comply with it by 30 June 2004. This firm expectation fell short, because of the resistances of many member states. ${ }^{62}$ A meeting of the Justice and Home Affairs Council on 2-3 June 2005 gave evidence that an agreement was still far from being achieved. The presidentin-office of the Council, the Luxemburger Luc Frieden, said during a press conference: "We had a very political discussion about that framework decision today. I think this is less a legal document but rather more a political document ... The draft framework decision, as amended many times by me and the working group over the past months, has found large support though not unanimous." 63

The main obstacle had been, he recognised, the different points of view in the member states on the freedom of speech:

In some countries that means that freedom of expression knows almost no boundaries, certainly no boundaries imposed through criminal law sanctions. For others freedom of expression does have limits. Those limits that freely elected parliaments put into the criminal code, where the interests of others are in conflict with some fundamental human rights. This is a debate that one can have for ages.

Less diplomatic newspaper reports unveil some interesting background details. ${ }^{64}$ On that occasion, the major opponent was Roberto Castelli, justice minister in Silvio Berlusconi's centre-right government, who announced that Italy was going to revise its laws on the freedom of speech, as a consequence of a trial initiated against the writer and journalist Oriana Fallaci for offences against Islam, and therefore he could not approve any decision of the Council before the Italian 
parliament had passed a decision on this issue. But Italy was not the only state with concerns on this issue. Even before there had been differences between France and some Scandinavian states, which refused to give legal assistance in cases of Holocaust deniers prosecuted under French justice. The United Kingdom also maintained its reservations.

The progress of the Framework decision stopped for some time, until in January 2007, with the beginning of the German presidency of the European Union, the German justice minister, Brigitte Zypries, announced her intention to bring about its adoption in order to extend the legislation criminalising the denial of genocides, notably the Holocaust, to all the member states of the European Union. ${ }^{65} \mathrm{~A}$ wave of critical reactions immediately followed, focusing - under the input of Zypries' statement - only on the opportunity of prosecuting the denial of the Holocaust, and not of other historical events. The British political scientist Timothy Garton Ash wrote in the Guardian on January $18^{66}$ that this initiative, however well-intentioned, was "very unwise ... [and] it would further curtail free expression - at a time when that is under threat from many quarters". The German historian Eberhard Jäckel, in an interview on February 1 to Deutschlandradio, ${ }^{67}$ also asserted that the denial of the Holocaust was "a stupid thing to do", which, however, did not need to be punished unless it incited hatred, and which could be combated more effectively by information. In Italy, a wide-ranging discussion took place in January, when the Italian justice minister, Clemente Mastella, immediately followed his German counterpart in proposing a law criminalising the denial of the Holocaust in Italy. ${ }^{68}$ This initiative also resulted in an outcry from Italian historians: ${ }^{69}$ in one single day, more than 200 scholars signed a petition asserting that such a law was dangerous, useless and counterproductive, on the grounds: that it would provide deniers with "the opportunity to present themselves as defenders of freedom of expression"; that in its efforts to impose historical truth, the state would expose this truth to the risk of losing all legitimacy and would undermine "confidence in the free confrontation of stances and in free historiographical and intellectual research"; and that laws criminalising incitement to violence, incitement to racial hatred, and the praising of crimes against humanity already exist in Italy. The petition concluded with the assertion that civil society alone was empowered to struggle against Holocaust denial by means of "a cultural fight, by ethics and by steadfast policy". In the face of such opposition and outrage, Mastella modified his bill by eliminating all references to Holocaust denial and by turning it into a modification of the so-called Mancino law (legge Man(ino $)^{70}$ of 1993 , which prosecuted racial discrimination, by imposing tougher penalties only on those who "disseminate ideas of racial superiority". ${ }^{71}$ In the event, this proposed law was never tabled for discussion in the Italian parliament. Also the French association Liberté pour l'Histoire protested against the Framework decision, pointing out, among other things, the "perverse effects" of the Gayssot law. ${ }^{72}$

The concern of historians spread also beyond the borders of the European Union. In particular, the general assembly of the International Committee of Historical Sciences (ICHS), held in Beijing on 17-18 September 2007, approved a motion expressing great alarm at this possible intrusion of the law into the field of historical research, and inviting all affiliated organisations to thoroughly discuss the matter with their members; moreover, the ICHS decided to organise a special session on this issue at its next international congress, which took place in Amsterdam on 22-28 August 2010. ${ }^{73}$ A few days before the Beijing meeting, the American Historical Asso- 
ciation issued a communication concerning the Framework decision, stating that any scientific research may only be assessed by experts belonging to the same research field. Therefore, if a historian should distort his evidence, the only measures to be taken against him, by colleagues specialised in the same field, should be the exclusion from academic posts and, in extreme cases, from publications. And it concluded: "If any other body, especially a body with the right to initiate legal proceedings and impose penalties, seeks to influence the course of historical research, the result will inevitably be intimidation of scholars and distortion of their findings." ${ }^{" 74}$

The criticism of historians did not influence the march of the Framework decision, which now speeded up towards its fulfilment. On 17 April 2007, the Council of the European Union issued a new draft. ${ }^{75}$ In this phase a new problem arose: the three Baltic countries, Poland and Slovenia demanded that the crimes perpetrated by the Soviet regime be included in the Framework decision. ${ }^{76}$ This initiative was not extemporaneous: three years before, in 2006, the Parliamentary Assembly of the Council of Europe had voted a resolution which called for the international condemnation of the crimes of totalitarian communist regimes, not only those of the past, but also those still in power. ${ }^{77}$

This demand encountered opposition, for instance from the United Kingdom, ${ }^{78}$ and eventually its proponents abandoned it in exchange for the following declaration, appended to the text of the draft, which promised that the issue would be reconsidered in the future:

The Framework Decision is limited to crimes committed on the grounds of race, colour, religion, descent or national or ethnic origin. It does not cover crimes committed on other grounds, e.g. by totalitarian regimes. However, the Council deplores all of these crimes ... The Berlin declaration adopted on 25 March 2007 stated that "European integration shows that we have learnt the painful lessons of a history marked by bloody conflict". In that light the Commission will organise a public European hearing on crimes of genocide, crimes against humanity and war crimes committed by totalitarian regimes as well as those who publicly condone, deny, grossly distort or trivialise them, and emphasises the need for appropriate redress of injustice and - if appropriate - submit a proposal for a framework decision on these crimes.

The public hearing on the crimes of totalitarian regimes, mentioned in this declaration, was organised a year later, on 8 April 2008, during Slovenia's presidency of the European Union. Many speakers harshly condemned the double standard towards Nazi and communist crimes, which was widespread in western Europe for cultural and political reasons, and which was reflected by the draft of the Framework decision. ${ }^{79}$ The lenient attitude towards Russia and its president, Vladimir Putin, who extolled the role of the Soviet army as the liberator of Europe, was also blamed. Because of that, the states which were once behind the "Iron Curtain" now felt that their suffering under the Soviet Union and their domestic communist regimes was not acknowledged in the new Europe. Moreover, the current concept of genocide was criticised for excluding political and social groups, a decision which was taken by the United Nations in 1948, when the Convention on the Prevention and Punishment of the Crime of Genocide was approved, as a result of the pressure of the Soviet Union, and which has been adopted by the statute of the International 
Criminal Court. ${ }^{80} \mathrm{At}$ the end of the hearing, the Lithuanian delegation proposed a set of initiatives to investigate the crimes of communist and other totalitarian regimes in Europe and to promote awareness of them: among the proposals was the establishment of a day of commemoration for their victims on 23 August, the anniversary of the signing of the Molotov-Ribbentrop pact. ${ }^{81}$ Thus, both Germany and the Soviet Union were given equal responsibility for the outbreak of the Second World War. This demand was fulfilled only a few months later, when, on 23 September 2008, the European Parliament declared August 23 as the "European Day of Remembrance for Victims of Stalinism and Nazism".82

After passing through a debate in the European Parliament on 29 November 2007,83 the final text of the Framework Decision was approved by the Council of the European Union on 28 November 2008 and entered into force on 6 December $2008 .{ }^{84} \mathrm{Art} .1$ \& 1 opens, as usual, with a reference to racism and xenophobia:

1. Each Member State shall take the measures necessary to ensure that the following intentional conduct is punishable:

(a) publicly inciting to violence or hatred directed against a group of persons or a member of such a group defined by reference to race, colour, religion, descent or national or ethnic origin;

(b) the commission of an act referred to in point (a) by public dissemination or distribution of tracts, pictures or other material.

Then come two subparagraphs dealing with historical events and the related criminal conducts of "publicly condoning, denying or grossly trivialising", which, unlike the first version of 2001, are evenly attributed to all genocides, crimes against humanity and war crimes:

(c) publicly condoning, denying or grossly trivialising crimes of genocide, crimes against humanity and war crimes as defined in Articles 6, 7 and 8 of the Statute of the International Criminal Court, directed against a group of persons or a member of such a group defined by reference to race, colour, religion, descent or national or ethnic origin when the conduct is carried out in a manner likely to incite to violence or hatred against such a group or a member of such a group;

(d) publicly condoning, denying or grossly trivialising the crimes defined in Article 6 of the Charter of the International Military Tribunal appended to the London Agreement of $8 \mathrm{Au}$ gust 1945, directed against a group of persons or a member of such a group defined by reference to race, colour, religion, descent or national or ethnic origin when the conduct is carried out in a manner likely to incite to violence or hatred against such a group or a member of such a group.

According to art. $3 \S 1$, all these criminal conducts are "punishable by criminal penalties of a maximum of at least between 1 and 3 years of imprisonment".

In art. 1 § 1 (c) and (d) one can observe an important limitation on the prosecution, which was lacking in the first version of 2001: namely, that the aforementioned crimes cannot be prose- 
cuted unless they have a racist or xenophobic aim and are likely to incite to violence or hatred. That means, that only qualified criminal conducts can be prosecuted. By that, historical research seems to be safe enough, but interpreting what "likely to incite" means is a slippery slope.

In the following paragraphs of art. 1, there is a set of clauses which define possible additional restrictions to the application field of the previous norms, which were included in order to avoid conflicts with the peculiarities of the different juridical systems and traditions of the member states, thus giving them an important flexibility in the adoption of the Framework decision.

Two clauses concerning the criminal conducts are declared by art. $1 \S 2$ :

For the purpose of paragraph 1, member states may choose to punish only conduct which is either carried out in a manner likely to disturb public order or which is threatening, abusive or insulting.

The reference to public order meets, for instance, the requirements of Germany, which in fact annexed to the text of the Framework decision a reservation on this point. ${ }^{85}$ The following reference to the character of being "threatening, abusive or insulting" matches British legislation, which punishes "acts intended or likely to stir up racial hatred" perpetrated by "threatening, abusive or insulting words or behaviour, or ... any written material which is threatening, abusive or insulting". 86

Paragraph 4 touches the crucial point of the definition of the courts which are entitled to rule on historical events:

Any Member State may, on adoption of this Framework Decision or later, make a statement that it will make punishable the act of denying or grossly trivialising the crimes referred to in paragraph 1(c) and/or (d) only if the crimes referred to in these paragraphs have been established by a final decision of a national court of this Member State and/or an international court, or by a final decision of an international court only.

This clause was absent both from the Joint Action and from the first draft of the Framework decision, and has very relevant consequences. In fact, if the power is given only to international courts, the range of historical events which can be involved is quite limited. The international courts have up to now been the Nuremberg tribunal, the International Criminal Court, which has nonretroactive competence but can only judge crimes committed after 1 July 2002, ${ }^{87}$ and the $a d$ hoc international tribunals, such as those on the former Yugoslavia and Rwanda. Of course, this limitation does not solve the root problem, because historical research on these recent crimes, and on futures ones, remains under fire. But at least previous historical events, such as those which have been object of the French memory laws or of Ukrainian legislation, are excluded. On the contrary, the competence of national courts has potentially no time limits, especially as they mainly follow laws passed by national parliaments, as one can see in the case of the Ukrainian court condemning Stalin for genocide. This clause has given rise to a very differentiated landscape: an historical event can be considered a crime against humanity in one member state and 
not in another, and opinions regarding it can be punished in one member state but not in another. One can easily imagine the consequences of this for the free movement of historians or even for the translation of history books.

This final version of the Framework decision also included art. 7 (Constitutional rules and fundamental principles), which gave more guarantees to the member states in terms of protection of freedom of expression. This article was absent in the first drafts and evidently reflects the tensions that characterised the long process of the finalisation of this text:

1. This Framework Decision shall not have the effect of modifying the obligation to respect fundamental rights and fundamental legal principles, including freedom of expression and association, as enshrined in Article 6 of the Treaty on European Union.

2. This Framework Decision shall not have the effect of requiring Member States to take measures in contradiction to fundamental principles relating to freedom of association and freedom of expression, in particular freedom of the press and the freedom of expression in other media as they result from constitutional traditions or rules governing the rights and responsibilities of, and the procedural guarantees for, the press or other media where these rules relate to the determination or limitation of liability.

The breadth of free space granted by this quite indeterminate article seemed excessive to the European Commission, which quite unusually inserted into the minutes of the Council a statement which expresses its disagreement as an annex to the Framework decision:

However, the Commission considers that Article 7(2) might be interpreted as allowing national law to prevail over Union law. In this connection, the Commission draws attention to the primacy of Union law. ${ }^{88}$

In this annex one finds not only this statement from the European Commission but also others expressed by some member states, which stress their own points of view and reservations on the implementation of the Framework decision. Among them there is the special concern with communism of some member states. Latvia asserted that the Framework decision should also encompass the crimes committed by communist regimes, and expressed a strong plea for putting both Nazi and communist crimes on the same level. ${ }^{89}$ Poland also joined the Latvian position on the inclusion of communist crimes, ${ }^{90}$ but in addition it stressed a particular point concerning the German occupation during the Second World War. It proposed a new criminal conduct, that of "public gross distortion", with special reference to the use of the expression "Polish concentration camps", which was considered as "shifting the responsibility for crimes committed for racist and xenophobic reasons ... from the actual perpetrators thereof". ${ }^{11}$ In fact, for many years Polish diplomacy has been engaged in combating the use of the term "Polish concentration camps" to refer to Auschwitz, Treblinka and so on, which surfaces from time to time in the media. ${ }^{92}$ This expression is certainly wrong and misleading, because it conflates the geographical location of the Nazi concentration camps with their historical perpetrators. But with this statement, the Polish government goes far beyond a diplomatic intervention aiming to redress a mistake, and seeks to make use of judicial power to punish a mistake. 
Finally, very interesting is the attitude of France, which has declared that it will limit the competence of the Framework decision only to crimes which have been condemned by an international court. ${ }^{93}$ This position goes against the previous politics of the French memory laws, which have, in fact, experienced a turnaround because of recent domestic debates. In 2008, a parliamentary commission on historical memory, after consulting many historians, philosophers and jurists, declared that, even if the existing French memory laws could not be abolished, no more laws concerning historical events should be introduced, especially if they foresee a criminal prosecution, and invited the French government to enter a statement to art. $1 \S 4$ of the Framework decision. ${ }^{94}$

\section{The adoption of the Framework decision by EU member states}

According to art. $10 \S 1$ of the Framework decision, the general deadline for adoption was 28 November 2010, but up to the end of July 2011 many states had yet to do this. Those which have already adopted it give a motley picture, even more than expected looking at the clauses inserted in the text and to the appended statements.

A very interesting case is Hungary because it provides clear evidence of the political biases that these laws have reflected. The Framework decision was first adopted in February 2010, in art. 269/C of the Hungarian penal code, which punished with three years' imprisonment "anyone who in public infringes the dignity of victims of the Holocaust, or denies the reality of, or doubts or trivialises the Holocaust". ${ }^{95}$ The law placed heavy limitations on the application of the Framework decision: it was purely a law against Holocaust denial, thus excluding the provisions of art. 1 § 1 (c). The prime minister then was Gordon Bajnai, of the Hungarian Socialist Party (MSZP). Soon afterwards, the political balance of forces changed, with the victory of the rightwing parties in the elections of 11 and 25 April 2010. The new government was led by Viktor Orbán, leader of the Hungarian Civic Union (Fidesz), which formed a coalition with the Christian Democratic People's Party (KDNP) and the Movement for a Better Hungary (Jobbik), and one of the first bills approved by the new government was the amendment of art. $269 / \mathrm{C},{ }^{96}$ which replaced the specific mention of the Holocaust with genocide and other crimes against humanity perpetrated by both Nazi and communist regimes. Neither version indicates which courts are entitled to judge historical events, and restricting clauses, such as those on the incitement to violence or hatred, or disturbing public order, foreseen by the Framework decision, are also absent. Such a norm can therefore lead to abuses.

Among the states once behind the "Iron Curtain", Lithuania approved on 15 June 2010 art. 1702 of its penal code, ${ }^{97}$ which also explicitly mentions communist crimes: it punishes the public condoning, denial or gross trivialisation of genocide and other crimes against humanity or war crimes as defined in legal acts of the European Union or of the Republic of Lithuania (thus meaning their parliaments, a new authority besides the courts) or by a final decision of a Lithuanian or international court. It then adds the aggression of the Soviet Union and Germany against Lithuania during the Second World War, the aforementioned crimes perpetrated by the Soviet Union and by Germany, and finally other serious crimes against its citizens perpetrated in 1990-1991, during the independence struggle against the Soviet Union. These conducts can be punished only 
if they are deemed threatening, abusive or insulting, or to disturb public order, and the penalty is a fine or restriction of liberty for up to two years.

In 2009, Latvia amended its penal code, ${ }^{98}$ imposing the penalty of no less than five years' imprisonment or community work on "a person who commits public glorification of genocide, crime against humanity, crime against peace or war crime or public denial or acquittal of implemented genocide, crime against humanity, crime against peace or war crime". ${ }^{99}$ The definition of the criminal conducts is a bit different from the Framework decision, notably through the absence of "gross trivialisation" and its replacement by "glorification". There is no indication of which courts are entitled to rule on historical events. Looking at the statement annexed to the Framework decision, one might be surprised that Latvia does not mention communist crimes: in any case, they must be considered as part of the general formulation.

There are also other states which do not explicitly mention Nazi or communist crimes, but which prefer a generic reference without indication of the perpetrators.

Slovenia, even before the final approval of the Framework decision, published in May 2008 a new penal code, in which art. 297 on "Public incitement to hatred, violence or intolerance" punishes by imprisonment of up to two years whoever "denies, diminishes the significance of, approves, disregards, ridicules, or advocates genocide, the Holocaust, crimes against humanity, war crimes, aggression or other criminal offences against humanity". ${ }^{100}$ The set of criminal conducts is thus enlarged, with the addition of "ridicule", which endangers cartoonists, for example.

Slovakia in 2009 adopted the Framework decision with section 424a of its penal code, which punishes with one to three years' imprisonment the conduct of condoning, denying or "seriously depreciating" a crime of genocide, a crime against humanity or a war crime defined as such by an international court whose jurisdiction is recognised by the Slovak Republic. ${ }^{101}$

On 13 April 2011 the Bulgarian National Assembly adopted the Framework decision by making some amendments to the country's penal code..$^{102}$ Among them, art. 419a punishes with imprisonment from one to five years the denial, justification or gross trivialisation of crimes against peace and humanity, in cases where these conducts are dangerous or violent or stir up hatred and target individuals or groups of people defined by "race, colour, religion, descent or national or ethnic origin".

In March 2011, Germany adopted both the Framework decision and the Additional protocol to the Convention dealing with cybercrime. ${ }^{103}$ The only change to art. $130 \S 1$ of the Strafgesetzbuch was the addition of individuals as targets, whereas before only groups were mentioned. This article, as we have seen, only dealt with the Holocaust. Concerning the other crimes against humanity or war crimes, nothing has been changed in the penal code because - as one reads in the preparatory report for this law - they are already covered by art. 140 of the Strafgesetzbuch, which punishes with a prison sentence of up to three years or a fine the public approval of a wide array of crimes, from sexual offences to high treason to counterfeiting of money, including crimes against humanity and war crimes in general. ${ }^{104}$ 
Romania considers that its legislation fully covers the requirements of the Framework decision, and therefore deems no further legal changes as necessary. ${ }^{105}$ The same decision has been taken by Portugal. ${ }^{106}$ In fact, as shown above, both states already punish various forms of denial and related crimes.

Malta adopted, on 17 July 2009, an amendment to its penal code ${ }^{107}$ which closely follows the Framework decision. The new article, $82 \mathrm{~B}$, punishes by imprisonment for a term between eight months to two years

Whosoever publicly condones, denies or grossly trivialises genocide, crimes against humanity and war crimes directed against a group of persons or a member of such a group defined by reference to race, colour, religion, descent or national or ethnic origin when the conduct is carried out in a manner

(a) likely to incite to violence or hatred against such a group or a member of such a group

(b) likely to disturb public order or which is threatening, abusive or insulting.

The following article, $82 \mathrm{C}$, includes in the same way crimes against peace, which it defines as

(a) the planning, preparation, initiation or waging of a war of aggression, or a war in violation of international treaties, agreements or assurances

(b) participation in a common plan or conspiracy for the accomplishment of any of the acts referred to in paragraph (a).

This definition copies the wording of article 6 of the Charter of the International Military Tribunal. But once more, there is no indication of the other courts which are entitled to define the criminal nature of historical events.

Other member states continue in their previous policy of punishing only racist behaviour in general but not specific forms of denial and other related criminal behaviours, thus ignoring the characteristic feature of the Framework decision.

The United Kingdom considers that the Framework decision is already covered by the Public Order Act of 1986 and therefore no change is needed. ${ }^{108} \mathrm{~A}$ close insight into the British point of view and preoccupation about the risks for freedom of expression can be gained from the debates of the House of Lords in 2007. The upper house expressed concern about the language used in art. 1 for the definition of the criminal conduct, in particular concerning the restrictions of "likely to disturb public order" or "threatening, abusive or insulting" and the vague meaning of "grossly trivialising". ${ }^{109}$ Also the prosecution of Holocaust denial was considered problematic, and in its reply, the government asserted that it did not intend to make it a criminal offence in the United Kingdom, as this would represent "an unnecessary infringement of freedom of expression", unless it was expressed in a "threatening, abusive, or insulting way and incites racial hatred, or is likely to do so", because in this case it would be already unlawful under the Public Order Act 1986. ${ }^{110}$

A similar stance has been taken by Ireland, ${ }^{111}$ on the basis of the Prohibition of Incitement to Hatred Act of 1989, which punishes any oral or written expression or behaviour which are "threat- 
ening, abusive or insulting and are intended or, having regard to all the circumstances, are likely to stir up hatred", and by Sweden, in particular on the base of chap. $16 \S 8$ of its penal code, which prosecutes many forms of hate speech. ${ }^{112}$ In Denmark sect. $266 \mathrm{~b}$ of the penal code ${ }^{113}$ is considered to comply with the Framework decision. ${ }^{114}$ Also the Netherlands has not made any changes to its penal code, as announced in the statement annexed to the minutes of the Framework decision, where it declared that

Articles 137c, 137d and 137e of the Dutch Criminal Code give a broad criminalisation of inciting to hate or violence, of insulting or discriminating because of amongst others race and religion. The term "race" includes also the characteristics skin colour, origin and national or ethnic decent. Under the scope of these Articles also fall condoning, denying or grossly trivialising of the international crimes, referred to in Article1 subparagraphs $\mathrm{c}$ and d, as far as such a conduct incites to hate or violence, insults or discriminates because of race or religion. ${ }^{115}$

In May 2011 Finland adopted the Framework decision by an amendment of the penal code which sharpened the punishment of racist and discriminatory conducts, but which did not mention the denial and similar conducts related to genocide and crimes against humanity. ${ }^{116}$

In Greece, which at present only punishes hate speech and racial discrimination, a justice minis-

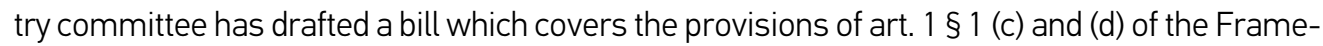
work decision, with the condition that the definition of these events as crimes has been established by a national or international court. The foreseen punishment equals a maximum imprisonment of two years and a pecuniary penalty ranging from $€ 1,000-3,000 .{ }^{117}$ As of July 2011 , this bill has not yet been tabled in parliament.

Finally, no initiatives or decisions for the adoption of the Framework decision have been taken up to July 2011 by the other member states.

\section{Conclusions}

The many objections made to the Framework decision during its long history have brought about a final text which gives great latitude to member states in the process of adoption, and, as one can see from the current state of this process, this latitude has been widely exploited. All in all, the original aim of the Framework decision, the harmonisation of the penal provisions of the member states, can be considered to have failed for the moment. But even in its current weakened form, the Framework decision cannot be considered harmless and ineffective. In fact, it has caused the legislation on the punishment of denial and the other related criminal conducts to be adopted by member states which previously ignored it. In addition it has also fuelled the ongoing history wars in eastern Europe between Russia and its neighbours. Under President Vladimir Putin, the memory of the Great Patriotic War has been successfully reshaped as a main founding myth of the new state, together with a certain normalisation of Stalin. ${ }^{118}$ This vision obviously clashes with the negative vision of the Soviet Union's victory and of its consequences that is nurtured in the former Soviet but now independent republics and in others states which were 
behind the "Iron Curtain". The conflict between Russia and Ukraine has already been dealt with. Another relevant incident in this clash was the removal of the monument to the Soviet soldier from the centre of Tallinn to a military cemetery on 27 April 2007, which aroused the indignation of Estonia's Russian minority and of the Russian government and public opinion. The idea of dismantling Soviet monuments has also been debated in Latvia ${ }^{119}$ and in Poland, ${ }^{120}$ and an additional reason for outrage in Russia was the annual march held in Riga to commemorate the Latvian Waffen-SS, who fought against the Red Army. ${ }^{121}$

There was a double response from the Russian side: a law and a commission. United Russia, the party supporting Putin and his successor, Dmitry Medvedev, introduced on 6 May 2009 a bill to the Duma, which punished with a fine of up to 300,000 roubles or imprisonment of up to three years the misrepresentations of the Nuremberg tribunal or of national trials or tribunals based on the Nuremberg tribunal aimed at the total or partial rehabilitation of Nazism and Nazi criminals, or the criminalisation of any actions undertaken by the member states of the anti-Hitler coalition, as well as the approval or denial of Nazi crimes against peace and humanity. The penalties were sharpened (a fine up to 500,000 roubles and five years' imprisonment) if the culprit was an on-duty official or if these ideas were spread through the mass media. ${ }^{122} \mathrm{~A}$ few days later, on 15 May 2009, Medvedev signed a decree for the establishment of a presidential commission "to counter attempts to falsify history to the detriment of Russia's interests", among whose 28 members were mostly politicians and officials of Russia's armed forces and of the intelligence service, with only three historians selected. ${ }^{123}$

The combination of the two tools could prove very effective in prosecuting unwelcome historical opinions. Both the bill and the commission met strong criticism both in Russia (for instance, from the human rights organisation Memorial and by a group of historians and intellectuals in St Petersburg) and abroad (among others by Liberté pour l'Histoire and by the American Historical Association). ${ }^{124}$ But the bill, even though it was approved by the Duma's legislative commission, was not supported in the event by the government because of legal inconsistencies in the text and because it could result in undesirable foreign policy consequences. ${ }^{125}$ This stance can be interpreted as evidence for a changed attitude on Medvedev's part towards the evaluation of the Soviet past and his policy of appeasement with Russia's western neighbours, which can also be seen in his condemnation of Stalin for crimes against his citizens, ${ }^{126}$ in his visit to Katyn together with Poland's President Bronisław Komorowski'27 and in the fact that in November 2010 the Duma recognised Stalin's responsibility for this massacre. ${ }^{128}$ In this new political context, the bill was resubmitted by United Russia to the Duma on 16 April 2010 in a different form, which only punishes "public approval or denial of Nazi crimes against peace and security of humanity determined by the Nuremberg tribunal verdict", and with the same penalties. ${ }^{129}$ The punishment of accusations against the Soviet Union has thus disappeared. A positive outcome, for the moment, but, in any case, another piece of evidence for the political bias in history.

The Framework decision has thus legitimised and supported the trend of passing criminal legislation on history, and its effects are not over, not only because of the foreseen possibility of the emergence of a new, similar text on crimes of genocide, crimes against humanity and war crimes committed by all totalitarian regimes, with the communist ones being the clear target, 
but also because art. $10 \S 3$ establishes that before 28 November 2013 the European Council shall review the text in the light of the implementation by member states. According to the European Commission's statement on art. $7 \S 2$, a conflict can be expected with the member states that have not fully complied with the provisions of the Framework decision. The game is still on and its outcome will depend on the attitude of member states which have up to now resisted. In this context, one must underline the evolution of France's attitude, which after opening the Pandora's box of the Gayssot law, had the courage and determination of sealing it with the Accoyer report, listening to the opposition of historians and other members of civil society, and, thus, putting a first stop to the trend of the criminalisation of historical discourse.

\section{Postscript}

This article was in press when the trend of French politics was reversed once more. On 22 December 2011, the National Assembly approved, on its first reading, a bill which extends the penal provisions of the Gayssot law to those who have "disputed or minimised in an extremist way ("contesté ou minimisé de façon outrancière") the existence of one or more crimes of genocide defined by art. 211-1 of the penal code and recognised as such by the French law". This bill has been officially presented as the implementation of the EU Framework decision, but actually it contradicts the French statement annexed to it. This bill was introduced by MP Valérie Boyer of the Union for a Popular Movement, President Sarkozy's party, and subsequently the Socialist Party declared its intention to reintroduce again to the Senate, where the Left has the majority since the September 2011 elections, the bill on the Armenian genocide approved by the National Assembly in 2006 but repealed by the Senate in May 2011. Political observers have stressed internal political reasons for this new bill, which has provoked a heated reaction from the Turkish government (Natalie Nougayrède, "Coup de froid entre la France et la Turquie", Le Monde, 22 Dec 2011; Patrick Roger, "Les députés pénalisent la négation des génocides", Le Monde, 23 Dec 2011; Guillaume Perrier, "Génocide arménien: Ankara sanctionne Paris", Le Monde, 24-26 Dec 2011). Immediate criticism has also come from the association Liberté pour l'Histoire (Françoise Chandernagor, "Lois mémorielles: un monstre législatif", Le Figaro, 29 Dec 2011; Pierre Nora, "Lois mémorielles: pour en finir avec ce sport législatif purement français", Le Monde, 28 Dec 2011). 


\section{NOTES}

1 See the call for rehabilitation of fascism made in 2000 in Italy by postfascist members of the centreright coalition led by Silvio Berlusconi (Luigi Cajani, “L'histoire, les lois, les mémoires: Sur quelques conflits récents en Europe", Revue française de Pédagogie 165 (2008), 65-76, here 66-68.

2 This was one of the main issues debated at the World Conference against Racism held 2001 in Durban, South Africa. See Michelle E. Lyons, "World Conference against Racism: New Avenues for Slavery Reparations", Vanderbilt Journal of Transnational Law 35 (2002), 1235-1268.

3 For a literature review, see Yaroslav Bilinsky, "Was the Ukrainian Famine of 1932-1933 Genocide?", Journal of Genocide Research 1 (1999), 147-156.

$4 \quad$ Ukrainian law N³76-V of 28 Nov 2006, Vidomosti Verkhovnoyi Rady Ukrayiny 2006, No. 50, 504.

5 Parliament of Canada, Debates of the Senate (Hansard), 2nd Session, 39th Parliament, Vol 144, Issue 63.

6 European Parliament resolution of 23 October 2008 on the commemoration of the Holodomor, the Ukraine artificial famine (1932-1933), Official Journal of the European Union, 21 Jan 2010, C 15 E/78.

7 Gosudarstvennaya Duma, Evening plenary session, 2 Apr 2008.

8 Parliamentary Assembly of the Council of Europe, Doc. 12173, 1 Mar 2010, Commemorating the Victims of the Great Famine (Holodomor) in the former USSR, Appendix 3.

9 Parliamentary Assembly of the Council of Europe, Report of the sitting of 27 Apr 2010.

10 Parliamentary Assembly of the Council of Europe, Resolution 1723 (2010).

11 Parliamentary Assembly of the Council of Europe, Doc. 12173, 1 Mar 2010, Commemorating the Victims of the Great Famine (Holodomor) in the former USSR, Report.

12 "Kyiv court to consider appeal against Yanukovych for his statement on famine of 1930s", Kyiv Post, 14 Jun 2010.

13 "Kyiv Court of Appeals sees nothing wrong in president's statement on Holodomor", Kyiv Post, 8 Dec 2010.

14 "Ukraine court finds Bolsheviks guilty of Holodomor genocide", RIA Novosti, 13 Jan 2010.

15 "Legal precedent in Ukraine: journalist allowed to doubt Holodomor as genocide", RIA Novosti 11 Mar 2010.

16 Denial of Holocaust (Prohibition) Law, 5746-1986, art. 1. It was passed by the Knesset on the Ist Tammuz, 5746 (8 Jul 1986) and published in Sefer Ha-Chukkim No. 1187 of the 9th Tammuz, 5746 (16 Jul 1986), 196.

17 Loi n90-615 du 13 juillet 1990 tendant à réprimer tout acte raciste, antisémite ou xénophobe. On the enforcement of this law see La lutte contre le négationnisme. Bilan et perspectives de la loi du 13 juillet 1990 tendant à réprimer tout acte raciste, antisémite ou xénophobe Actes du colloque du 5 juillet 2002 à la cour d'appel de Paris Commission nationale consultative des Droits de l'homme (CNCDH), Paris: La documentation française, 2003.

18 The crimes are the following: “a) Crimes against peace: namely, planning, preparation, initiation or waging of a war of aggression, or a war in violation of international treaties, agreements or assurances, or participation in a common plan or conspiracy for the accomplishment of any of the forego- 
ing; (b) War crimes: namely, violations of the laws or customs of war. Such violations shall include, but not be limited to, murder, ill-treatment or deportation to slave labour or for any other purpose of civilian population of or in occupied territory, murder or ill-treatment of prisoners of war or persons on the seas, killing of hostages, plunder of public or private property, wanton destruction of cities, towns or villages, or devastation not justified by military necessity; (c) Crimes against humanity: namely, murder, extermination, enslavement, deportation, and other inhumane acts committed against any civilian population, before or during the war; or persecutions on political, racial or religious grounds in execution of or in connection with any crime within the jurisdiction of the Tribunal, whether or not in violation of the domestic law of the country where perpetrated."

Madeleine Rebérioux, “Le Génocide, le juge et l'historien”, L'Histoire 138 (1990), 92-94.

20 Tribunal de Grande Instance de Paris, 1re Chambre, 1re Section, Jugement rendu le 1er Juillet 1981.

21 Madeleine Rebérioux, “Contre la loi Gayssot”, Le Monde, 21 May 1996.

22 Loi n. 2001-70 du 29 janvier 2001 relative à la reconnaissance du génocide arménien de 1915.

23 Assemblée Nationale, 12 Oct 2006: Proposition de loi tendant à réprimer la contestation de l'existence du génocide arménien.

24 Sénat, Séance du mercredi 4 mai 2011, Journal Officiel de la République Française, 5 May 2011.

25 Loi n. 2001-434 du 21 mai 2001 tendant à la reconnaissance, par la France, de la traite et de l'esclavage en tant que crime contre l'humanité, art. 1.

26 Ibid., art. 2.

27 Loi n. 2005-158 du 23 février 2005 portant reconnaissance de la Nation et contribution nationale en faveur des Français rapatriés, art. 1.

28 Ibid., art. 4.

29 See the petition "Colonisation: non à l'enseignement d'une histoire officielle", Le Monde, 25 Mar 2005. For a detailed reconstruction of these events, see Matthias Middell: "«Ce n'est pas à l'Etat de dire comment on enseigne l'histoire»: Geschichte und Geschichtswissenschaft in Frankreich", Neue Politische Literatur 2/3 (2006), 187-202; René Rémond, Quand l'État se mêle de l'histoire, Paris: Stock, 2006; and the dossier “L'État et ses mémoires", Regards sur l'actualité 325 (2006).

30 Olivier Pétré-Grenouilleau, Les traites négrières: Essai d'histoire globale, Paris: Gallimard, 2004.

31 Christian Sauvage, “Un prix pour Les traites négrières”, Journal du Dimanche, 12 Jun 2005.

32 Libération, 13 Dec 2005.

33 Béatrice Gurrey, Jean-Baptiste de Montvalon, "Colonisation: Chirac évite un débat au Parlement", Le Monde, 27 Jan 2006.

34 “L'historien échappe au procès grâce à Elkabbach”, Libération, 4 Feb 2006.

35 "Bundesverfassungsgesetz, mit dem das Verbotsgesetz geändert wird (Verbotsgesetz-Novelle 1992)", Bundesgesetzblatt für die Republik Österreich, 19 Mar 1992, 743.

36 Bundesrepublik Deutschland, Strafgesetzbuch, section 130, §3.

37 Thomas Wandres, Die Strafbarkeit des Auschwitz-Leugnens, Berlin: Duncker \& Humblot, 2000, $110-112$.

38 Loi tendant à réprimer la négation, la minimisation, la justification ou l'approbation du génocide com- 
mis par le régime national-socialiste allemand pendant la seconde guerre mondiale, 23 Mar 1995.

39 Chambre des Représentants de Belgique, DOC 51 1284/011, 21 Apr 2005: Projet de Loi modifiant les articles 259bis, 314bis, 504quater, 550bis et 550ter du Code pénal et la loi du 23 mars 1995 tendant à réprimer la négation, la minimisation, la justification ou l'approbation du génocide commis par le régime national-socialiste allemand pendant la seconde guerre mondiale.

40 Kenneth Bertrams and Pierre-Olivier de Broux, "Du négationnisme au devoir de mémoire: l'histoire est-elle prisonnière ou gardienne de la liberté d'expression?", Revue de Droit de l'Université libre de Bruxelles 35 (2007), 75-134, here 188-119.

41 Loi du 19 juillet 1997 complétant le code pénal en modifiant l'incrimination du racisme et en portant incrimination du révisionnisme et d'autres agissements fondés sur des discriminations illégales.

42 Ordonanța de urgență a Guvernului no. 31/2002, art. 1 and 2.

43 Ibid., art. 6.

44 Loi fédéral 18 Jun 1993, in force since 1 Jan 1995.

45 Lei n. ${ }^{59 / 2007}$ de 4 de Setembro Vigésima terceira alteração ao Código Penal, aprovado pelo Decreto-Lei n. ${ }^{\circ}$ 400/82, de 23 de Setembro.

46 Ley Orgánica 10/1995, de 23 de noviembre, del Código Penal.

47 “Negar el genocidio entra en el ámbito de la libertad de expresión, según el Constitucional”, El País, 17 Nov 2006. For the full text of the sentence, see Tribunal Constitucional de España, STC 235/2007.

48 Ustawa z dnia 18 grudnia 1998 r. o Instytucie Pamięci Narodowej - Komisji Ścigania Zbrodni przeciwko Narodowi Polskiemu, art. 1 and 2.

49 Ibid., art. 55.

50 Zákon ze dne 25. řijna 2000, kterým se mění zákon č. 140/1961 Sb., trestní zákon, ve znění pozdějších předpisů.

51 Pierre Vidal-Naquet, Les assassins de la mémoire: Un “Eichmann de papier"et autres essais sur le révisionnisme, Paris: La Découverte, 1991; François Dubuisson, “L'incrimination générique du négationnisme est-elle conciliable avec le droit à la liberté d'expression?", Revue de Droit de l'Université libre de Bruxelles 35 (2007), 135-195; Emanuela Fronza, "The Criminal Protection of Memory: Some Observations About the Offence of Holocaust Denial", in Ludovic Hennebel and Thomas Hochmann (eds), Genocide Denials and the Law, Oxford and New York: Oxford UP (2011), 155-181.

52 Henry R. Huttenbach, "From the Editor: Towards a Conceptual Definition of Genocide", Journal of Genocide Research 4/2 (2002), 167-175, here 167.

53 Scott Straus, "Contested Meanings and Conflicting Imperatives: A Conceptual Analysis of Genocide”, Journal of Genocide Research 3:3 (2001), 349-375.

54 Ben Kiernan, Blood and Soil: A World History of Genocide and Extermination from Sparta to Darfur, New Haven: Yale UP, 2007.

55 Anthony C. Grayling, Among the Dead Cities, London: Bloomsbury, 2006.

56 Emanuela Fronza, "Profili penalistici del negazionismo", Rivista italiana di diritto e procedura penale, n.s., 42 (1999), 1034-1074, here 1050, 1061-1062.

57 See, for instance, the Declaration Against Racism and Xenophobia issued 1986 by the European 
Parliament, the Council, the Representatives of the Member States, meeting within the Council, and the Commission (Official Journal of the European Communities, 25 Jun 1986, C 158/01, 1-3), and the recent Treaty on the Functioning of the European Union, art. 67 (2010).

58 "Joint Action of 15 July 1996 adopted by the Council on the basis of Article K.3 of the Treaty on the European Union concerning action to combat racism and xenophobia (96/443/ JHA)", Official Journal of the European Communities, 24 Jul 1996, L185/5, 5-7.

59 Ibid., Title I A.

60 "Proposal for a Council Framework Decision on combating racism and xenophobia", Official Journal of the European Communities, 26 Mar 2002, C 75 E, 269-273.

61 Source: Council of Europe, Treaty Office.

62 For some broad information on this phase of the negotiations on the Framework decision, see Marc Bell, "European Union Strategies to Combat Racism and Xenophobia as a Crime", in Rainer Nickel, Andrea Coomber, Marc Bell, Tansy Hutchinson and Karima Zahi, European Strategies to Combat Racism and Xenophobia as a Crime, Brussels: European Network Against Racism, 2003, 31 - 38.

63 Justice and Home Affairs, Press Release, 2 Jun 2005: "No agreement on the framework decision on combating racism and xenophobia at the Justice and Home Affairs Council." (www.eu2005.lu/en/actualites/ communiques/2005/06/02jai-rx/index.html) (all URLs in this article were last accessed on 31 Jul 2011).

64 Franco Papitto, “Razzismo, la UE non decide”, la Repubblica, 24 Feb 2005; “Direttiva UE sul razzismo. Castelli: la blocco per la Fallaci”, la Repubblica, 3 Jun 2005; Giacomo Galeazzi, "Il rinvio a giudizio per vilipendio dell'islam della giornalista. Castelli: dopo il «caso Fallaci» stop alla direttiva sul razzismo", La Stampa, 3 Jun 2005; Ivo Caizzi, "UE e razzismo, stop italiano legato al caso della Fallaci“, Corriere della Sera, 3 Jun 2005.

65 lan Traynor, "Germany bids to outlaw denial of Holocaust across continent", The Guardian, 16 Jan 2007.

66 Timothy Garton Ash, "A blanket ban on Holocaust denial would be a serious mistake", The Guardian, 18 Jan 2007.

67 “Historiker Jäckel: Holocaust-Leugner mit Ignoranz strafen, interview on Deutschlandradio", 1 Feb 2007 (www.dradio.de/dkultur/sendungen/kulturinterview/588968).

68 Italy's position on this issue is quite erratic. Roberto Castelli, who had in 2005 rejected the proposal, is a member of the Northern League (Lega Nord), which was part of the centre-right coalition, while Clemente Mastella was in 2007 member of the centre-left government, but Zypries' initiative was warmly supported also by Franco Frattini, European Commissioner for justice, freedom and security and vice-president of the European Commission, member of the House of Freedoms (Casa delle Libertà), which was part of the centre-right coalition (European Union, press release 26 Jan 2007: Statement from Vice-president Frattini, on behalf of the European Commission, on the occasion of the International Day of Commemoration of the victims of the Holocaust (27 January)).

69 "Noi storici contro la legge che punisce chi nega la Shoah", l'Unità, 23 Jan 2007. The petition was initiated by Marcello Flores, Simon Levis Sullam and EnzoTraverso.

70 Legge n. 205/93, "Misure urgenti in materia di discriminazione razziale, etnica e religiosa”, Gazzetta Ufficiale, 26 Jun 1993, n. 148.

71 Alberto Custodero, "Mastella presenta la sua legge: 12 anni per apologia della Shoah", la Repubblica, 
25 Jan 2007.

72 Pierre Nora, “Liberté pour l'histoire!", Le Monde, 10 Oct 2008.

73 General Assembly of the ICHS, Beijing, 17-18 September 2007 (www.cish.org).

74 "AHA Statement on the Framework Decision of the Council of the European Union on the Fight against Racism and Xenophobia", Perspectives 45/8 (2007).

75 Council of the European Union, 8544/07, DROIPEN 43, Brussels, 17 Apr 2007.

76 Cécile Barbier, Dalila Ghailani and Philippe Pochet, “European Briefing: Digest”, Journal of European Social Policy 17 (2007), 271-284, here 277.

77 Parliamentary Assembly of the Council of Europe, Resolution 1481 (2006): Need for international condemnation of crimes of totalitarian communist regimes (adopted on 25 Feb 2006).

78 House of the Lords, Committee Office: The Lord Grenfell, Chairman of the Select Committee on the European Union, to the Rt Hon Vernon Coaker MP, Parliamentary Under Secretary of State, Home Office, 19 Apr 2007.

79 Sandra Kalniete, "Divergences within European politics with regard to communist totalitarianism", in Peter Jambrek (ed.), Crimes Committed by Totalitarian Regimes, Ljubljana: Slovenian Presidency of the Council of the European Union, 2008, 245-250; Girts Valdis Kristovskis, "The need for a reappraisal of the European history", ibid., 223-225.

80 Ronaldas Racinskas, “Historical Justice for Europe: Why, When And How?", in Jambrek, Crimes Committed by Totalitarian Regimes, 13-19; Dainius Žalimas, "The Need for Equal Treatment of Nazi and Soviet Crimes", ibid., 81-84.

81 Emanuelis Zingeris, "Transition from the "Gulag Empire" to the Western Civilisation: Issues of Remembrance and Education", in Jambrek, Crimes Committed by Totalitarian Regimes, 255-258.

82 Declaration of the European Parliament on the proclamation of 23 August as European Day of Remembrance for Victims of Stalinism and Nazism, Official Journal of the European Union, 14 Jan 2010, C 8/ E 57-59.

83 European Parliament legislative resolution of 29 Nov 2007 on the proposal for a Council Framework Decision on combating certain forms and expressions of racism and xenophobia by means of criminal law (11522/2007 - C6-0246/2007 - 2001/0270 (CNS)).

84 Council Framework decision 2008/913/JHA of 28 Nov 2008 on combating certain forms and expressions of racism and xenophobia by means of criminal law, Official Journal of the European Union, 6 Dec 2008, L 328/55-L 328/58. Comprehensive analysis of this text can be found in: Laurent Pech, "The Law of Holocaust Denial in Europe. Toward a (qualified) EU-wide Criminal Prohibition", in Hennebel and Hochmann (eds), Genocide Denials, 185-234; Paolo Lobba, "La lotta al razzismo nel diritto penale europeo dopo Lisbona: Osservazioni sulla decisione quadro 2008/913/GAl e sul reato di negazionismo", Ius17@unibo.it 3 (2011), forthcoming; and, with special attention to the comparison with the Belgian laws, in Bernadette Renauld, "La decision-cadre 2008/913/JAl du Conseil de l'Union européenne: du nouveau en matière de lute contre le racism?", Revue trimestrielle des droits de l'homme 21/81 (2010), 119-140.

85 "Germany assumes in particular that, for the purposes of implementation, the term "öffentliche Friede" as used in the relevant corresponding provisions of German criminal law is covered by the term "public order" as employed in Article 1 paragraph 2 of the Framework Decision" (Council of the European Un- 
ion, Interinstitutional File: 2001/0270 (CNS), 15699/1/08 REV 1 DROIPEN 91, Brussels, 25 Nov 2008, 5).

86 Public Order Act of 1986, art. $18 \S 1$.

87 See the Rome Statute of the International Criminal Court, art. 11.

88 Council of the European Union, Interinstitutional File: 2001/0270(CNS), 15699/1/08 REV 1, DROIPEN 91, Brussels, 25 Nov 2008, 4.

89 Council of the European Union, Interinstitutional File: 2001/0270(CNS), 16351/1/08 REV 1 DROIPEN 94, Brussels, 26 Nov 2008, 5-7.

90 Council of the European Union, Interinstitutional File: 2001/0270(CNS), 15699/1/08 REV 1 DROIPEN 91, Brussels, 25 Nov 2008, 4.

91 Council of the European Union, Interinstitutional File: 2001/0270(CNS), 16351/1/08 REV 1 DROIPEN 94, Brussels, 26 Nov 2008, 8.

92 Ministerstwo Spraw Zagranicznych Rzeczypospolitej Polskiej, False terminology in the foreign media used in reference to Nazi German concentration camps in occupied Poland: Report by the Information Department of the Ministry of Foreign Affairs of the Republic of Poland; Government information on Polish foreign policy presented by the Minister of Foreign Affairs, Prof. Adam Daniel Rotfeld, at the session of the Sejm on 21 Jan 2005.

93 "France declares, in accordance with Article 1(4), that it will make punishable the act of denying or grossly trivialising the crimes referred to in paragraph 1(c) and/or (d) only if the crimes referred to in these paragraphs have been established by a final decision of an international court" (Council of the European Union, Interinstitutional File: 2001/0270(CNS), 16351/1/08 REV 1 DROIPEN 94, Brussels, 26 Nov 2008, 7).

94 Assemblée Nationale, Rapport d'information fait en application de l'article 145 du règlement au nom de la mission d'information sur les questions mémorielles, Président-Rapporteur M. Bertrand Accoyer, (enregistré à la Présidence de l'Assemblée nationale le 18 novembre 2008), 181, 184.

95 2010. évi XXXVI. törvény a Büntető Törvénykönyvről szóló 1978. évi IV. törvény módosításáról.

96 2010. évi LVI. törvény a Büntető Törvénykönyvről szóló 1978. évi IV. törvény módosításáról (entered into force on 24 Jul 2010).

97 Baudžiamojo kodekso 95 straipsnio pakeitimo bei papildymo, kodekso papildymo 170-2 straipsniu ir kodekso priedo papildymo istatymas, 2010 m. birželio15 d. Nr. XI-901, Vilnius.

98 Grozījumi Krimināllikumā, 74.1 pants. Genocīda, nozieguma pret cilvēci, nozieguma pret mieru un kara nozieguma attaisnošana (adopted on 21 May 2009 and entered into force on 1 Jul 2009).

99 The English translation of the Latvian penal code is provided by the governmental Tulkošanas un terminoloǵijas centrs (Translation and Terminology Centre).

100 Ukaz o razglasitvi Kazenskega zakonika (KZ-1), Razglašam Kazenski zakonik (KZ-1), ki ga je sprejel Državni zbor Republike Slovenije na seji 20. maja 2008, Uradni list RS, št. 55/2008 z dne 4. 6. 2008.

101 Zákon č. 300/2005 Z. Z. z 20. mája 2005 Trestný Zákon v znení zákona č. 650/2005 Z. z., v znení zákona č. 692/2006 Z. z., v znení zákona č. 218/2007 Z. z., v znení zákona č. 491/2008 Z. Z., v znení zákona č. 497/2008 Z. Z., v znení zákona č. 498/2008 Z. z., v znení zákona č. 257/2009 Z. Z.

102 Darzhaven vestnik 33 (26 Apr 2011). The amendments entered into force on 27 May 2011.

103 Gesetz zur Umsetzung des Rahmenbeschlusses 2008/913/JI des Rates vom 28. November 2008 
zur strafrechtlichen Bekämpfung bestimmter Formen und Ausdrucksweisen von Rassismus und Fremdenfeindlichkeit und zur Umsetzung des Zusatzprotokolls vom 28. Januar 2003 zum Übereinkommen des Europarats vom 23. November 2001 über Computerkriminalität betreffend die Kriminalisierung mittels Computersystemen begangener Handlungen rassistischer und fremdenfeindlicher Art, 16 Mar 2011.

104 Deutscher Bundestag - 17. Wahlperiode, Drucksache 17/3124: Entwurf eines Gesetzes zur Umsetzung des Rahmenbeschlusses 2008/913/JI des Rates vom 28. November 2008 zur strafrechtlichen Bekämpfung bestimmter Formen und Ausdrucksweisen von Rassismus und Fremdenfeindlichkeit und zur Umsetzung des Zusatzprotokolls vom 28. Januar 2003 zum Übereinkommen des Europarats vom 23. November 2001 über Computerkriminalität betreffend die Kriminalisierung mittels Computersystemen begangener Handlungen rassistischer und fremdenfeindlicher Art, Begründung A, III.

105 Personal letter from the Ministry of Justice, Department of European Affairs, 26 Oct 2010.

106 Personal letter from the Ministério da Justiça, Direcção-Geral da Política de Justiça, 3 Aug 2011.

107 Act No. XI of 2009: An Act further to amend the Criminal Code, Cap. 9.

108 Personal letter from the Foreign and Commonwealth Office, Europe Directorate, 20 Jan 2010.

109 House of the Lords, Committee Office: The Lord Grenfell, Chairman of the Select Committee on the European Union, to the Rt Hon Vernon Coaker MP, Parliamentary Under Secretary of State, Home Office, 19 Apr 2007, 24 May 2007.

110 House of Lords Debates, vol. 691, 20 Apr 2007, col. WA 97.

111 Personal letter from the Department of Justice and Law Reform, 22 Sept 2010.

112 Regeringskansliet, Justititie departementet Sverige, Underrättelse om nationella åtgärder för att uppfylla Sveriges förpliktelser i Europeiska unionen, letter to the Secretary of the Council of the European Union and to the Secretary of the European Commission, 20 Sept 2010.

113 (1) "Any person who publicly or with the intention of dissemination to a wide circle of people makes a statement or imparts other information threatening, insulting or degrading a group of persons on account of their race, colour, national or ethnic origin, belief or sexual orientation, shall be liable to a fine, simple detention or imprisonment for a term not exceeding two years. (2) When handing down the punishment, it is to be considered as an aggravating circumstance that the statement is in the nature of propaganda."

114 Justitsministeriet, Civil- og Politiafdelingen, Supplerende samlenotat vedrørende de sager der forventes behandlet på rådsmødet (retlige og indre anliggender) og mødet i de blandede udvalg på ministerniveau med deltagelse henholdsvis af Norge og Island og af Schweiz den 27.-28. november 2008, 6 Nov 2008.

115 Council of the European Union, Interinstitutional File: 2001/0270(CNS), 15699/1/08 REV 1 DROIPEN 91, Brussels, 25 Nov 2008, 6.

116 Laki 511/2011 rikoslain muuttamisesta Annettu Helsingissä 13 päivänä toukokuuta 2011, Suomen Säädöskokoelma, 20 May 2011.

117 Athanasios Chouliaras, "Transposing the Framework Decision on Combating Racism and Xenophobia into the Greek Legal Order”, Eurocrim 1 (2011), 39-44.

118 Maria Ferretti, “La memoria spezzata. La Russia e la guerra”, Italia contemporanea 245 (2006), 525- 


\section{Criminal Laws on History: The Case of the European Union}

565.

119 "WWII veterans call for removal of Soviet monument in Riga", The Baltic Times, 22 Jan 2007.

120 "Poland should also remove Soviet monuments - Katyn Committee", RIA Novosti, 28 Apr 2007.

121 Tony Paterson, “Thousands pay tribute to Latvia's fallen Nazi troops”, The Independent, 17 Mar 2010.

122 Gosudarstvennaya Duma, Zakonoproekt № 197582-5: O vnesenii izmenenij v Ugolovnyj kodeks Rossijskoj Federacii i v stat'ju 151 Ugolovno-processual'nogo kodeksa Rossijskoj Federacii (po voprosu ustanovlenija ugolovnoj otvetstvennosti za posjagatel'stvo na istoričeskuju pamjat' $v$ otnošenii sobytij, imevšich mesto $v$ period Vtoroj mirovoj vojny); Nikolay Kaposov, "Le débat russe sur les lois mémorielles", Le débat 158 (2010), 50-59, here 50.

123 Ibid., 55.

124 Ibid., 56.

125 Boris Vishnevsky, “Za obelenje černych pjaten”, Novaya Gazeta, 25 Jan 2010.

126 Andrew Osborn, "Russia's President Dmitry Medvedev condemns Stalin", The Telegraph, 30 Oct 2009.

127 “Poland's Komorowski to visit Katyn massacre site via Moscow", RIA Novosti, 8 Apr 2011.

128 Jan Cienski, “Medvedev visit marks turn in Polish relations”, Financial Times, 5 Dec 2010.

129 "United Russia party seeks to criminalise denial of Nazi crimes", RIA Novosti, 30 Mar 2010; Nikolay Koposov, Pamjat' strogogorežima: Istorija i politika v Rossii, Moskva: NLO, 2011, 243. 